\title{
A Study on the Preparation of Microbial and Nonstarch Polysaccharide Enzyme Synergistic Fermented Maize Cob Feed and Its Feeding Efficiency in Finishing Pigs
}

\author{
Biaosheng Lin $\mathbb{D}^{1}{ }^{1}$ Jianbin Yan, ${ }^{2}$ Zhilong Zhong, ${ }^{3}$ and Xintian Zheng $\mathbb{D}^{1,4}$ \\ ${ }^{1}$ College of Life Science, Longyan University, Longyan 364012, China \\ ${ }^{2}$ Yi Zhitai Biotechnology (Longyan) Co., Ltd., Longyan 364012, China \\ ${ }^{3}$ Longyan Zhenggao Biotechnology Co., Ltd., Longyan 364012, China \\ ${ }^{4}$ Key Laboratory of Fujian Universities Preventive Veterinary Medicine and Biotechnology, Longyan University, \\ Longyan 364012, China
}

Correspondence should be addressed to Xintian Zheng; 58650779@qq.com

Received 31 August 2020; Revised 30 October 2020; Accepted 2 November 2020; Published 16 November 2020

Academic Editor: Aqeel Ahmad

Copyright ( 92020 Biaosheng Lin et al. This is an open access article distributed under the Creative Commons Attribution License, which permits unrestricted use, distribution, and reproduction in any medium, provided the original work is properly cited.

\begin{abstract}
$1000 \mathrm{~g}$ maize cob mixed material was synergistically fermented by adding $2.5 \%$ composite probiotics and $0.06-0.08 \%$ NSP (nonstarch polysaccharide) enzyme to prepare fermented feed, and its effectiveness as feed for fattening pigs was investigated. The results showed that the appearance, texture, and nutrient quality of maize cobs significantly improved after fermentation, the total number of bacteria was $4.5 \times 10^{10} \mathrm{CFU} / \mathrm{g}$, and the protein content was $7.1 \%$. Compared to the control group, the pigs in the $6 \%$ fermented maize cob feed experimental group showed significantly increased daily feed intake, daily weight gain, and nutrient digestion rate $(p<0.05)$ and reduced feed conversion ratio $(p<0.05)$. Most indicators including slaughter performance and meat quality significantly improved. In addition, beneficial bacteria including Lactobacillus in the intestines of the finishing pigs significantly increased, and pathogenic bacteria including Escherichia coli in the intestines and feces were found to be significantly reduced $(p<0.05)$. The intestinal crypt depth, VH/CD ratio, and ileal mucosal immunity of the finishing pigs also significantly improved $(p<0.05)$. The cytokine content and gene expression of sIgA, IL- 8 , and TNF- $\alpha$ were found to be significantly increased $(p<0.05)$. It could be concluded that the addition of $6 \%$ fermented maize cob feed to the diets of finishing pigs could promote their growth, improve their production performance and slaughter performance meat quality, and enhance their intestinal microecological balance and immunity.
\end{abstract}

\section{Introduction}

As a main feeding crop worldwide, maize has long been widely used in animal husbandry [1]. Maize cob is the central core after removing kernels from the maize ear. The annual output of corn in China exceeds 200 million tons, of which maize cob production accounts for approximately $10 \%$, ultimately causing an extremely large output that exceeds 20 million tons [2]. With the development of science and technology, the field of maize cob deep processing has expanded continuously, and maize cobs have been processed into series of high value-added products, such as furfuryl alcohol, xylose, activated carbon, and glucose [3-5]. Maize cobs have also been widely used to produce ethanol [6-7], manufacture food packaging [8], extract oil [9], produce cultivation material for crops [10], and produce feedstuffs [11-13]; thus, maize cobs have high potential and value that should be fully accessed. Studies have shown that maize cobs primarily contain $32-36 \%$ cellulose, $35-40 \%$ hemicellulose, $17-20 \%$ lignin, and a small amount of ash and other components [14-15]. Their crude fiber content is high, and their palatability is poor. As the digestive utilization rate of direct feeding of 
animals is low, it is rarely used in animal production. Thus, preparing microbially fermented maize cob feeds is an economically feasible approach [16-17].

For many years, probiotics, such as Lactobacillus, yeasts, and Bacillus subtilis, have been widely used in feed fermentation [18-19]. In practice, however, simple microbial fermentation alone causes low protease content, which does not fulfill actual production needs. In addition, antagonism between microbial strains may also exist, which consequently affects the fermentation of products [20-21]. Synergistic microbial fermentation refers to fermentation that is subjected to enzymatic hydrolytic processing in conjunction with some amounts of probiotic bacteria. The addition of enzyme preparations overcomes the issue of insufficient enzyme production during fermentation by a single type of microorganisms and improves the utilization efficiency of feed macromolecules by the microorganisms [22-23]. In addition, a variety of organic acids and aroma substances that were produced by these probiotics during fermentation significantly improve the palatability of feed and regulate the intestinal health of animals [24-25].

Thus, this study combined the advantages of microbial probiotics in improving intestinal health and nonstarch polysaccharide (NSP) enzymes in degrading the principal nutritional components of maize cobs to develop a synergistic microbial fermented feed and investigate its feeding efficiency in finishing pigs. High-quality mixed feed suitable for finishing pigs was developed, thereby transforming waste into a valuable resource, extending the industrial chain of agricultural byproducts and waste materials, such as maize cobs, and providing a basis for its application in animal husbandry.

\section{Materials and Methods}

2.1. Materials. Maize cobs (Denghai 605) were purchased from market (Jinxiu Agricultural and Sideline Products Processing Co., Ltd., Qihe, China), and its moldy and rotten parts were removed, dried at $60 \sim 70^{\circ} \mathrm{C}$ for $4 \mathrm{~h}$, and then crushed by $50 \sim 100$-mesh sieve. Freeze-dried bacterium blended powder containing $6.2 \sim 7.7 \times 10^{9} \mathrm{CFU} / \mathrm{g}$ of Lactobacillus fermentum, $1.3 \times 4.6 \times 10^{8} \mathrm{CFU} / \mathrm{g}$ of Saccharomyces cerevisiae, and $2.5 \sim 4.2 \times 10^{8} \mathrm{CFU} / \mathrm{g}$ of Bacillus subtilis and NSP enzyme containing 10000 20000 U/g activity of xylanase, $1000 \sim 1500 \mathrm{U} / \mathrm{g}$ activity of $\beta$-glucanase, $200 \sim 300 \mathrm{U} / \mathrm{g}$ activity of mannanase, 2000 4000 U/g activity of cellulase, and $100 \sim 300 \mathrm{U} / \mathrm{g}$ of pectinase were all provided by Fujian Longyan Jinhe Animal Feed Co., Ltd., China. Fermenter and select PE (polyethylene) membrane with unidirectional permeability holes (purchased from the market) were 5 7layer thick and have permeability hole diameter 9-12 mm, oxygen permeation $2.25 \sim 4.42 \mathrm{~cm}^{3} / \mathrm{m}^{2}$.d.bar, and exhaust pressure $\quad 678 \sim 750 \mathrm{mmH}_{2} \mathrm{O}$. Duroc-Landrace-Yorkshire fattening pigs were purchased and housed in Yi Zhitai Biotechnology (Longyan) Co., Ltd. (Longyan, China).

2.2. Medium. Maize cob fermentation medium ( $1000 \mathrm{~g}$ ) consisted of $600 \mathrm{~g}$ maize cob, $30 \mathrm{~g}$ corn flour, $15 \mathrm{~g}$ brown sugar, $15 \mathrm{~g}$ compound multivitamins, $340 \mathrm{~mL}$ water, and
pH 6.0 6.5. Among them, compound multivitamin composition per kilogram is as follows: vitamin A 4000000 IU, vitamin D3 $1200000 \mathrm{IU}$, vitamin E $30000 \mathrm{IU}$, vitamin $\mathrm{K}_{3} 800 \mathrm{mg}$, vitamin $B_{1} 1000 \mathrm{mg}$, vitamin $B_{2} 3200 \mathrm{mg}$, vitamin $B_{6} 800 \mathrm{mg}$, vitamin $B_{12} 24 \mathrm{mg}$, D-pantothenic acid $14400 \mathrm{mg}$, folic acid $2800 \mathrm{mg}$, and niacin $24000 \mathrm{mg}$. In addition, NSP enzyme was added for another 0.6-0.8 g during fermentation.

2.3. Preparation of Fermented Maize Cob Feed. $25 \mathrm{~g}$ of bacterial powder was weighed for every $1000 \mathrm{~g}$ of material to be fermented. The bacterial powder was then activated by adding warm water at a temperature of $25-30^{\circ} \mathrm{C}$ and stirred thoroughly. The amount of water used was according to the manufacturer's formulation, and the warm water contained the amount of brown sugar specified in the formulation. The brown sugar was thoroughly mixed with the warm water described above. Raw materials were set up as specified by the formulation, mixed thoroughly, loaded into the fermenter, connected with the activated bacterial mixture, and mixed once again for closed fermentation. Fermentation conditions were as follows: fermentation temperature of $25-30^{\circ} \mathrm{C}$ and resting time of 5-7 d. The fermented material was suitable for feeding when its color became deeper and darker and developed a clear scent.

2.4. Determination of Fermented Feed Product Performance. The appearance of the product before and after fermentation, microbial strain content, and nutrient composition were analyzed. The microbial strain contents were measured by live bacteria plating. Crude protein, dry matter, crude ash, neutral detergent fiber, acid detergent fiber, crude fat, reducing sugar, calcium, phosphorus, and other nutrient components were analyzed by referring to conventional feed analysis methods [26].

2.5. Measurement Indices and Methods for Fermented Maize Cob Feed for Finishing Pigs. For the growth performance and nutrient consumption, a total of 200 healthy Duroc $\times$ (Landrace $\times$ Yorkshire) three-way crossbred finishing pigs weighing $60.12 \pm 0.75 \mathrm{~kg}$ were selected and randomly divided into 4 groups. Each group included 5 repetitions, and each repetition included 10 pigs (of similar weight) that were divided evenly between males and females for $60-120 \mathrm{~kg}$ feeding tests. The 4 groups included the control group and 3 experimental groups. The control group was fed a basic diet (Table 1, according to the NRC (2012) nutrient requirements for finishing pig), and the experimental groups were fed the basic diet supplemented with 4,6 , and $8 \%$ fermented maize cob feed-replacing the energy components, such as corn and soybean meal, of the basic diet. The addition of concentration ratios $(4 \%, 6 \%$, and $8 \%)$ was based on the addition ratio of conventional fermented feed in livestock and poultry animals and the results of prefeeding in the early stage of this experiment [27-28]. The growth performance and nutrient digestibility of each group of finishing pigs were analyzed in a finishing pig house with relatively stable and controlled conditions. Further, the growth performance indices of the average daily weight gain, feed intake, and feed conversion 
TABLE 1: Components and nutritional level of forages for tested pigs.

\begin{tabular}{lccr}
\hline Components of basic diet (\%) & \multicolumn{2}{c}{ Nutritional level } \\
Corn & $53 \sim 68$ & Energy (MJ.kg $\left.{ }^{-1}\right)$ & $15.68 \sim 15.97$ \\
\hline Bean cake CP (44\%) & $22 \sim 36$ & Crude protein (\%) & $12.65 \sim 19.38$ \\
Rice bran & $2 \sim 6$ & Dry matter (\%) & $86.25 \sim 88.97$ \\
Complex premix compound & $2 \sim 4$ & Crude fiber (\%) & $2.45 \sim 2.86$ \\
Total & 100 & Ca (\%) & $0.56 \sim 0.72$ \\
& & Available phosphorus (\%) & $0.24 \sim 0.31$ \\
& & Lysine (\%) & $0.85 \sim 1.00$ \\
\hline
\end{tabular}

ratio in finishing pigs that were fed fermented maize cob, rather than conventional feed, were investigated.

For the evaluation of the nutrient digestibility effects, titanium dioxide $\left(\mathrm{TiO}_{2}\right)$ was used as an external index for digestion tests. $0.1 \% \mathrm{TiO}_{2}$ was added to the experimental groups that were fed fermented feed, and both feed and fecal samples were collected from each group after prefeeding for 5 days. Gross energy (GE), dry matter (DM), crude protein (CP), ether extract (EE), crude ash (Ash), calcium levels (Ca), and phosphorus levels (P) in the samples were analyzed and determined to evaluate the effects of fermented maize cob feed on nutrient digestibility in finishing pigs. Ti contents were determined as described by Morgan et al. [29]. Lastly, the nutrient consumption rate (\%) was equal to the following: $[1-$ (Ti contents in feed samples/Ti contents in fecal samples) $\times$ (nutrient contents in fecal samples/nutrient contents in feed samples) $] \times 100$.

For the slaughter performance and meat quality, after testing, five finishing pigs from each experimental group were randomly selected for slaughter, and the slaughter performance, meat quality, muscle fat levels, and fatty acid levels of the pork were evaluated. Each index was measured as described by Panella-Riera et al. [30]. All pigs were slaughtered with a normal humane procedure, and all efforts were made to minimize suffering. The pigs were euthanized by electric shock and then dehaired, and the carcasses were dissected.

For intestinal performance and ileal mucosal immunity, after testing, fecal samples were aseptically collected from the rectum of the finishing pigs before slaughter, and the total bacteria and E. coli counts of the collected samples were measured (plate colony counting method, the same as below). The morphology of the intestinal tissue was examined at the time of slaughter, and the duodenum, jejunum, ileum, and cecum were isolated. Of these, the duodenum, jejunum, and ileum were stored in $10 \%$ neutral formalin buffer solution and frozen sections were prepared as described by $\mathrm{Hu}$ et al. [31]. Hematoxylin-eosin (HE) staining was then performed. The villus height (VH), crypt depth (CD), and VH/CD ratio were calculated. Chyme from the ileum and cecum was collected for microbial flora determination. Approximately $1.5 \mathrm{~cm}$ of the proximal distal ileum was treated with normal saline, frozen in liquid nitrogen, and stored in a $-80^{\circ} \mathrm{C}$ freezer. The double-antibody sandwich enzyme-linked immunosorbent assay (ELISA) method was used to measure the contents of secreted immunoglobulin A (sIgA), interleukin-8 (IL-8), and tumor necrosis factor- $\alpha$
TABle 2: Primer sequences for real-time PCR.

\begin{tabular}{lccc}
\hline Gene & Primer sequence $\left(5^{\prime}-3^{\prime}\right)$ & $\begin{array}{c}\text { Fragment } \\
\text { size }(\mathrm{bp})\end{array}$ & $\begin{array}{c}\text { Tm } \\
\left({ }^{\circ} \mathrm{C}\right)\end{array}$ \\
\hline IL-8 & $\begin{array}{l}\text { F: TTCGATGCCAGTGCATAAATA } \\
\text { R: CTGTACAACCTTCTGCACCCA }\end{array}$ & 176 & 60 \\
TNF- & F: CCAATGGCAGAGTGGGTATG & 116 & 60 \\
$\alpha$ & R: TGAAGAGGACCTGGGAGTAG & & \\
\hline
\end{tabular}

(TNF- $\alpha$ ) in the intestinal tissue supernatant. All kits were purchased from Nanjing Jiancheng Bioengineering Institute, and a real-time PCR assay was used to measure the mRNA expression of IL- 8 and TNF- $\alpha$. The real-time PCR reaction composition was as follows: $10.0 \mu \mathrm{L}$ of $2 \times$ Master Mix (Beijing Tiangen Biochemical Technology Co., Ltd.), $0.5 \mu \mathrm{L}$ of primer $\mathrm{F}(10 \mu \mathrm{M}), 0.5 \mu \mathrm{L}$ of primer $\mathrm{R}(10 \mu \mathrm{M})$, q.s. to a total volume of $20 \mu \mathrm{L}$ with diethyl pyrocarbonate- (DEPC-) treated water, and $1.2 \mu \mathrm{L}$ of cDNA $(30 \mathrm{ng} / \mu \mathrm{L})$. Primer pairs for each factor are shown in Table 2 [32]. The reaction procedure was as follows: $95^{\circ} \mathrm{C}$ for $30 \mathrm{~s}, 95^{\circ} \mathrm{C}$ for $5 \mathrm{~s}$, and $60^{\circ} \mathrm{C}$ for $35 \mathrm{~s} ; 40$ cycles. Further, the melting curve analysis was based on automated fluorescence measurements as follows: $60^{\circ} \mathrm{C}$ for $60 \mathrm{~s}$ and $95^{\circ} \mathrm{C}$ for $15 \mathrm{~s}\left(60^{\circ} \mathrm{C}-95^{\circ} \mathrm{C}\right)$. The $2^{-\Delta \Delta \mathrm{CT}}$ method was used to calculate the expression of each factor in the experimental groups with the addition of different amounts of fermented maize cob feed relative to the control group. $18 \mathrm{~S}$ RNA was used as the internal reference gene [33].

2.6. Statistical Analysis. All the data were sorted by Excel software, and then, one-way ANOVA program in SPSS software was used for single-factor ANOVA analysis, Waller-Duncan program for multiple comparison between groups. All data in test results were represented by the mean $\pm \mathrm{SD}$, and means were considered different when $p<0.05$.

\section{Results}

3.1. Measurement Results of Fermented Maize Cob Feed Product Performance. Results of the performance measurements of maize cob before and following fermentation are shown in Table 3. Maize cobs exhibited a deeper color following fermentation, which produces a transparent wine-like and lactic acid scent with a clear color and texture change. Compared to the levels before fermentation, the contents of crude protein, calcium, and phosphorus in maize cobs increased after fermentation, whereas dry matter, crude fat, 
TABle 3: Determination of maize cob composition before and after fermentation.

\begin{tabular}{|c|c|c|c|c|}
\hline \multicolumn{2}{|l|}{ Items } & Before processing & $\begin{array}{l}\text { After processing (added bacteria } \\
\text { but no NSP enzyme) }\end{array}$ & $\begin{array}{c}\text { After processing (added } \\
\text { bacteria and NSP enzyme) }\end{array}$ \\
\hline \multicolumn{2}{|l|}{ Visual evaluation } & $\begin{array}{c}\text { Yellowish brown, } \\
\text { powdery, tough, uniform } \\
\text { tissue, no obvious } \\
\text { fragrance, slightly dry }\end{array}$ & $\begin{array}{c}\text { Brown, with a certain } \\
\text { lactic acid and wine flavor, } \\
\text { soft texture, loose, slightly moist }\end{array}$ & $\begin{array}{c}\text { Dark brown, more } \\
\text { obvious lactic acid } \\
\text { and wine flavor, soft smell, } \\
\text { not pungent, loose, } \\
\text { soft, and moist }\end{array}$ \\
\hline Bacteria content & & - & $\begin{array}{c}\text { Total bacteria count: } 3.6 \times 10^{10} \\
\text { CFU/g, containing } 6.8 \times 10^{6} \\
\text { CFU/g of Lactobacillus } \\
\text { fermentum, } 5.1 \times 10^{6} \mathrm{CFU} / \mathrm{g} \\
\text { of Saccharomyces cerevisiae, } \\
3.5 \times 10^{10} \mathrm{CFU} / \mathrm{g} \text { of } \\
\text { Bacillus subtilis }\end{array}$ & $\begin{array}{c}\text { Total bacteria count: } 4.5 \times 10^{10} \\
\text { CFU/g, containing } 7.2 \times 10^{6} \\
\text { CFU/g of Lactobacillus } \\
\text { fermentum, } 7.4 \times 10^{6} \\
\text { CFU/g of Saccharomyces } \\
\text { cerevisiae, } 4.4 \times 10^{10} \\
\text { CFU/g of Bacillus subtilis }\end{array}$ \\
\hline \multirow{9}{*}{$\begin{array}{l}\text { Nutrient } \\
\text { composition (\%) }\end{array}$} & Crude protein & $3.4 \pm 0.09^{\mathrm{a}}$ & $5.9 \pm 0.13^{\mathrm{b}}$ & $7.1 \pm 0.15^{\mathrm{c}}$ \\
\hline & Dry matter & $97.1 \pm 1.89^{\mathrm{a}}$ & $96.5 \pm 2.21^{\mathrm{a}}$ & $92.9 \pm 2.16^{\mathrm{b}}$ \\
\hline & Crude ash & $2.9 \pm 0.01^{\mathrm{a}}$ & $2.1 \pm 0.12^{\mathrm{b}}$ & $1.8 \pm 0.08^{\mathrm{b}}$ \\
\hline & Neutral washing fiber & $88.5 \pm 0.87^{\mathrm{a}}$ & $70.3 \pm 1.78^{\mathrm{b}}$ & $61.5 \pm 2.21^{\mathrm{c}}$ \\
\hline & Acid detergent fiber & $42.6 \pm 2.52^{\mathrm{a}}$ & $42.2 \pm 2.03^{\mathrm{a}}$ & $39.8 \pm 1.12^{\mathrm{b}}$ \\
\hline & Crude fat & $0.52 \pm 0.12^{\mathrm{a}}$ & $0.34 \pm 0.11^{\mathrm{b}}$ & $0.29 \pm 0.09^{\mathrm{b}}$ \\
\hline & Reducing sugar & $2.15 \pm 0.11^{\mathrm{a}}$ & $1.42 \pm 0.12^{\mathrm{b}}$ & $1.18 \pm 0.13^{\mathrm{c}}$ \\
\hline & $\mathrm{Ca}$ & $0.12 \pm 0.02^{\mathrm{a}}$ & $0.28 \pm 0.05^{\mathrm{b}}$ & $0.33 \pm 0.03 b$ \\
\hline & $\mathrm{P}$ & $0.04 \pm 0.001^{\mathrm{a}}$ & $0.05 \pm 0.002^{\mathrm{b}}$ & $0.06 \pm 0.001^{\mathrm{b}}$ \\
\hline
\end{tabular}

Note:"-" means no value, all the data in the table were the determination results of corncob before and after fermentation at different batches, and five batches were determined. In the shoulder markers of peer data, The same letters indicate no significant difference $(p>0.05)$, and different letters indicate significant difference $(p<0.05)$, the same as below.

TABLE 4: Effect of fermented maize cob feed on growth performance of finishing pigs.

\begin{tabular}{lcccc}
\hline Group & Control group & $4 \%$ additive group & $\begin{array}{c}\text { Test group } \\
\text { 6\% additive group }\end{array}$ & $8 \%$ additive group \\
\hline Initial weight $(\mathrm{kg})$ & $59.93 \pm 3.41^{\mathrm{a}}$ & $60.21 \pm 4.21^{\mathrm{a}}$ & $60.13 \pm 1.54^{\mathrm{a}}$ & $60.25 \pm 2.24^{\mathrm{a}}$ \\
Final weight $(\mathrm{kg})$ & $118.69 \pm 2.65^{\mathrm{a}}$ & $120.32 \pm 3.21^{\mathrm{a}}$ & $121.36 \pm 2.65^{\mathrm{a}}$ & $121.63 \pm 1.65^{\mathrm{a}}$ \\
Average daily gain $(\mathrm{g} / \mathrm{d})$ & $691.29 \pm 20.12^{\mathrm{a}}$ & $707.18 \pm 25.36^{\mathrm{a}}$ & $720.35 \pm 22.12^{\mathrm{b}}$ & $722.12 \pm 18.69^{\mathrm{b}}$ \\
Average daily intake (g/d) & $2135.36 \pm 56.32^{\mathrm{a}}$ & $2145.98 \pm 74.25^{\mathrm{c}}$ & $2140.36 \pm 36.68^{\mathrm{b}}$ & $2141.32 \pm 56.32^{\mathrm{b}}$ \\
Feed conversion ratio & $3.09 \pm 0.07^{\mathrm{a}}$ & $3.03 \pm 0.05^{\mathrm{b}}$ & $2.97 \pm 0.06^{\mathrm{c}}$ & $2.97 \pm 0.05^{\mathrm{c}}$ \\
\hline
\end{tabular}

Note: the feeding time was July October 2019, the pretest period of feeding the basic diet before the formal test was $3 \mathrm{~d}$, and then, the formal feeding test was carried out for $85 \mathrm{~d}$.

neutral detergent fiber, acid detergent fiber, crude fat, and reducing sugar contents decreased. Compared to single bacterial fermentation, synergistic microbial fermentation of maize cob with the addition of NSP enzymes significantly increased each microbial strain population, fiber degradation, and protein contents $(p<0.05)$; the residual contents of dry matter, crude ash, and reducing sugar decreased. The results showed that the addition of NSP enzymes could increase the utilization efficiency of maize cob macromolecules and significantly improved the protein conversion efficiency. Furthermore, this addition also provided more energy for microbial strain growth and significantly increased the number of each microbial strain. Performance and Nutrient Consumption of Finishing Pigs.
As shown in Table 4, the daily feed intake significantly increased in every experimental group as the amount of fermented feed increased $(p<0.05)$, compared to the control group. Daily weight gain significantly increased $(p<0.05)$, whereas the feed conversion ratio was found to be reduced. When the amount of additive was $6 \%$, the daily weight gain and feed conversion ratio was significantly improved compared to that of the control and $4 \%$ additive groups $(p<0.05)$, with no significant differences compared to the $8 \%$ additive group.

Table 5 shows that gross energy, dry matter, organic matter, crude protein, crude fat, calcium levels, phosphorus levels, and other nutrient digestibility indices of fermented maize cob feed significantly increased compared to the control group $(p<0.05)$. Among these indices, when the amount of additive was $6 \%$, many nutrient digestibility 
TABLE 5: Effect of fermented maize cob feed on nutrient digestibility of finishing pigs.

\begin{tabular}{lcccc}
\hline Group & Control group & $4 \%$ additive group & $\begin{array}{c}\text { Test group } \\
6 \% \text { additive group }\end{array}$ & $8 \%$ additive group \\
\hline Total energy (\%) & $81.92 \pm 5.21^{\mathrm{a}}$ & $83.31 \pm 3.12^{\mathrm{b}}$ & $85.72 \pm 3.42^{\mathrm{c}}$ & $86.04 \pm 6.41^{\mathrm{c}}$ \\
Dry matter (\%) & $82.60 \pm 2.36^{\mathrm{a}}$ & $84.73 \pm 5.62^{\mathrm{b}}$ & $86.71 \pm 2.45^{\mathrm{c}}$ & $84.68 \pm 4.65^{\mathrm{b}}$ \\
Organic matter (\%) & $85.85 \pm 5.65^{\mathrm{a}}$ & $87.82 \pm 3.25^{\mathrm{b}}$ & $87.80 \pm 4.52^{\mathrm{b}}$ & $89.32 \pm 2.98^{\mathrm{c}}$ \\
Crude protein (\%) & $77.11 \pm 4.56^{\mathrm{a}}$ & $80.44 \pm 2.32^{\mathrm{b}}$ & $82.33 \pm 4.56^{\mathrm{c}}$ & $82.34 \pm 4.68^{\mathrm{c}}$ \\
Crude fat (\%) & $33.62 \pm 1.23^{\mathrm{a}}$ & $61.79 \pm 2.21^{\mathrm{b}}$ & $63.15 \pm 1.87^{\mathrm{c}}$ & $62.99 \pm 2.12^{\mathrm{c}}$ \\
$\mathrm{Ca}(\%)$ & $35.94 \pm 1.12^{\mathrm{a}}$ & $43.35 \pm 1.25^{\mathrm{b}}$ & $44.02 \pm 1.68^{\mathrm{bc}}$ & $44.93 \pm 1.59^{\mathrm{c}}$ \\
P (\%) & $51.01 \pm 1.67^{\mathrm{a}}$ & $54.20 \pm 2.25^{\mathrm{b}}$ & $56.13 \pm 2.20^{\mathrm{c}}$ & $55.99 \pm 4.36^{\mathrm{bc}}$ \\
\hline
\end{tabular}

TABLE 6: Effect of fermented maize cob feed on slaughter performance and meat quality of finishing pigs.

\begin{tabular}{|c|c|c|c|c|c|}
\hline Group & & Control group & \multicolumn{2}{|r|}{ Test group } & $8 \%$ additive group \\
\hline \multirow{6}{*}{ Slaughter performance } & Weight before slaughter (kg) & $118.69 \pm 2.65^{\mathrm{a}}$ & $120.32 \pm 3.21^{\mathrm{a}}$ & $121.36 \pm 2.65^{\mathrm{a}}$ & $121.63 \pm 1.65^{\mathrm{a}}$ \\
\hline & Carcass weight $(\mathrm{kg})$ & $84.41 \pm 2.21^{\mathrm{a}}$ & $86.30 \pm 2.35^{\mathrm{ab}}$ & $88.21 \pm 1.65^{\mathrm{b}}$ & $87.01 \pm 2.03^{\mathrm{ab}}$ \\
\hline & Dressing percentage (\%) & $71.12 \pm 1.56^{\mathrm{a}}$ & $72.56 \pm 2.31^{\mathrm{b}}$ & $72.68 \pm 2.14^{\mathrm{b}}$ & $71.54 \pm 1.89^{\mathrm{a}}$ \\
\hline & 10th ribbed back fat thick $(\mathrm{cm})$ & $2.80 \pm 0.32^{\mathrm{a}}$ & $2.78 \pm 0.24^{\mathrm{ab}}$ & $2.76 \pm 0.16^{\mathrm{b}}$ & $2.79 \pm 0.30^{\mathrm{ab}}$ \\
\hline & 10th costal muscle area $\left(\mathrm{cm}^{2}\right)$ & $37.45 \pm 1.13^{\mathrm{a}}$ & $37.94 \pm 1.36^{\mathrm{b}}$ & $38.14 \pm 1.34^{\mathrm{c}}$ & $38.10 \pm 1.42^{\mathrm{c}}$ \\
\hline & Thin meat rate $(\%)$ & $55.42 \pm 1.45^{\mathrm{a}}$ & $56.01 \pm 2.01^{\mathrm{ab}}$ & $56.32 \pm 1.36^{\mathrm{b}}$ & $55.69 \pm 1.37^{\mathrm{a}}$ \\
\hline \multirow{7}{*}{ Meat quality } & Meat color score & $2.12 \pm 0.13^{\mathrm{a}}$ & $3.11 \pm 0.16^{\mathrm{b}}$ & $3.20 \pm 0.35^{\mathrm{c}}$ & $3.22 \pm 0.21^{\mathrm{c}}$ \\
\hline & Marbling score & $2.32 \pm 0.21^{\mathrm{a}}$ & $3.16 \pm 0.21^{\mathrm{b}}$ & $3.26 \pm 0.26^{\mathrm{c}}$ & $3.24 \pm 0.16^{\mathrm{bc}}$ \\
\hline & $\mathrm{pH}_{45 \min }$ & $6.12 \pm 0.36^{\mathrm{a}}$ & $6.15 \pm 0.31^{\mathrm{a}}$ & $6.25 \pm 0.29^{b}$ & $6.25 \pm 0.38^{\mathrm{b}}$ \\
\hline & $\mathrm{pH}_{24 \mathrm{~h}}$ & $5.51 \pm 0.29^{\mathrm{a}}$ & $5.52 \pm 0.27^{\mathrm{a}}$ & $5.57 \pm 0.31^{\mathrm{b}}$ & $5.57 \pm 0.39^{\mathrm{b}}$ \\
\hline & Tenderness (N) & $30.52 \pm 1.03^{\mathrm{a}}$ & $23.44 \pm 0.98^{\mathrm{b}}$ & $23.15 \pm 1.12^{\mathrm{c}}$ & $23.21 \pm 1.03^{c}$ \\
\hline & Water loss rate (\%) & $42.36 \pm 1.13^{\mathrm{a}}$ & $42.22 \pm 1.12^{\mathrm{b}}$ & $42.12 \pm 1.25^{\mathrm{c}}$ & $42.20 \pm 1.20^{\mathrm{bc}}$ \\
\hline & Drip loss (\%) & $2.71 \pm 0.16^{\mathrm{a}}$ & $2.68 \pm 0.21^{\mathrm{a}}$ & $2.63 \pm 0.18^{\mathrm{b}}$ & $2.65 \pm 0.22^{\mathrm{b}}$ \\
\hline \multirow{5}{*}{$\begin{array}{l}\text { Muscle fat levels and } \\
\text { fatty acid levels }\end{array}$} & Meat fat (\%) & $2.31 \pm 0.26^{\mathrm{a}}$ & $2.35 \pm 0.21^{\mathrm{ab}}$ & $2.38 \pm 0.16^{\mathrm{b}}$ & $2.44 \pm 0.19^{c}$ \\
\hline & Monounsaturated fatty acid (\%) & $43.36 \pm 1.17^{\mathrm{a}}$ & $45.21 \pm 1.16^{\mathrm{b}}$ & $45.32 \pm 1.05^{\mathrm{bc}}$ & $45.38 \pm 1.21^{\mathrm{c}}$ \\
\hline & Polyunsaturated fatty acid (\%) & $11.15 \pm 0.21^{\mathrm{a}}$ & $10.65 \pm 0.32^{\mathrm{ab}}$ & $10.23 \pm 0.25^{\mathrm{bc}}$ & $10.02 \pm 0.29^{c}$ \\
\hline & Unsaturated fatty acid (\%) & $54.51 \pm 1.36^{\mathrm{a}}$ & $55.86 \pm 1.38^{\mathrm{b}}$ & $55.55 \pm 1.25^{\mathrm{d}}$ & $55.40 \pm 1.28^{\mathrm{c}}$ \\
\hline & Saturated fatty acid (\%) & $40.12 \pm 1.14^{\mathrm{a}}$ & $40.20 \pm 1.03^{\mathrm{ab}}$ & $40.22 \pm 0.89^{\mathrm{b}}$ & $40.23 \pm 0.97^{\mathrm{b}}$ \\
\hline
\end{tabular}

indices were significantly higher than in the $4 \%$ additive group $(p<0.05)$, with no significant differences compared to the $8 \%$ additive group.

3.3. Effects of Fermented Maize Cob Feed on Slaughter Performance and Meat Quality of Finishing Pigs. Table 6 shows that the addition of different proportions of fermented maize cob feed exhibited positive effects on most indices, such as slaughter performance, meat quality, muscle fat levels, and fatty acid levels, compared to those of the control group, but some indices (dressed weight, dressing percentage, tenth rib fat thickness, and percent lean) were not significantly improved with increased additive. Overall, the $6 \%$ additive condition significantly improved the slaughter performance and meat quality of finishing pigs $(p<0.05)$.

3.4. Effects of Maize Cob Fermented Feed on Intestinal Performance and Ileal Mucosal Immunity in Finishing Pigs. Figure 1(a) shows that different proportions of fermented maize cob feed did not significantly increase the villus height of finishing pigs compared to the control group, although crypt depth (Figure 1(b)) and VH/CD ratio (Figure $1(\mathrm{c})$ ) were found to be significantly decreased and increased, respectively, as the additive amount increased $(p<0.05)$. Further, intestinal morphology and structure were improved. The addition of fermented maize cob feed exhibited significant effects on the feces and intestinal microorganisms of the finishing pigs $(p<0.05)$. Compared to the control group, the microbial florae in the feces of finishing pigs increased and the number of $E$. coli significantly decreased $(p<0.05)$ as the amount of additive increased (Figure 2(a)), while Lactobacillus content in the ileum and cecum significantly increased and the number of $E$. coli decreased $(p<0.05)$ (Figures 2(b) and 2(c)). Fermented maize cob feed also significantly improved the ileum mucosal immunity of the finishing pigs $(p<0.05)$ (Figure 3$)$. Compared to the control group, the cytokine contents and expression of the corresponding immune factor genes in each experimental group increased as the amount of additive increased-all of which reached significance $(p<0.05)$. 


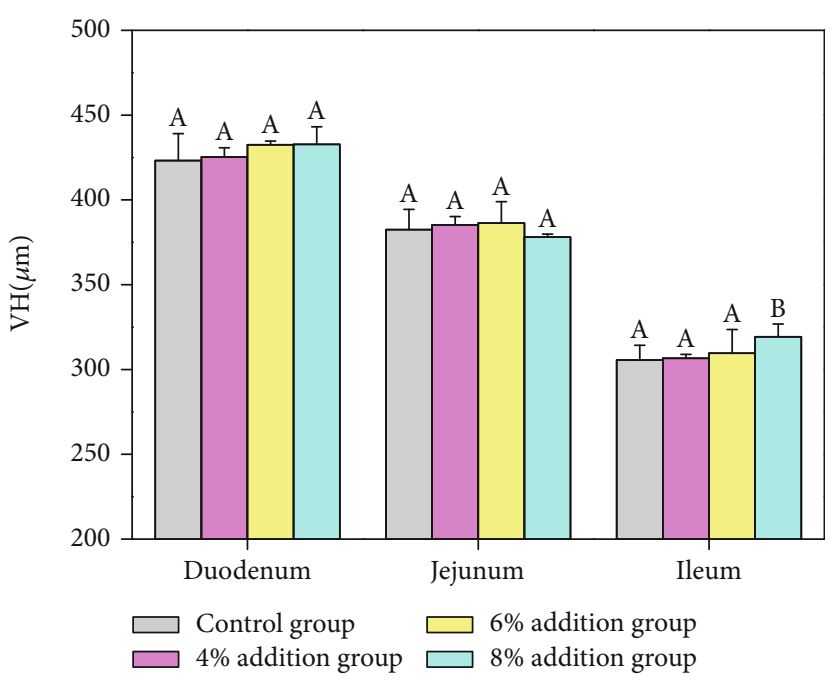

(a)

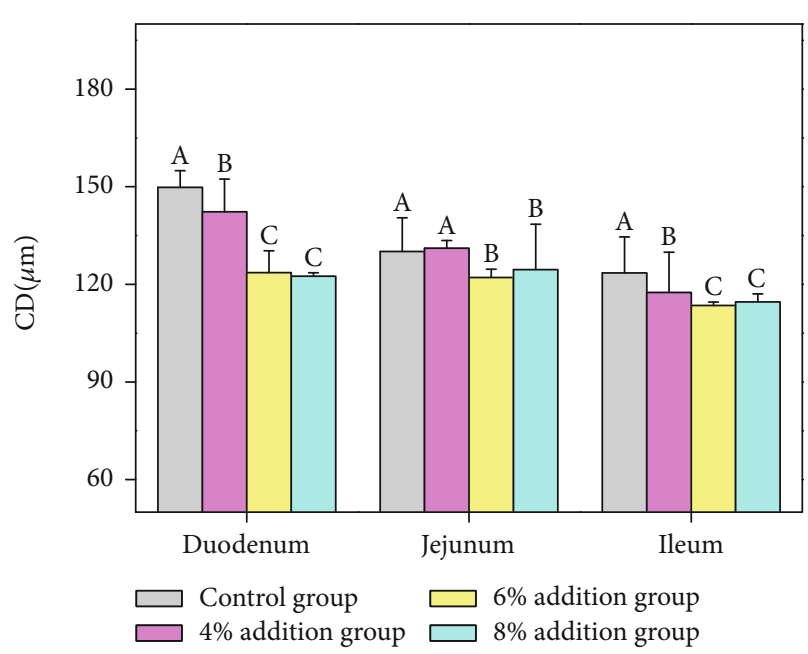

(b)

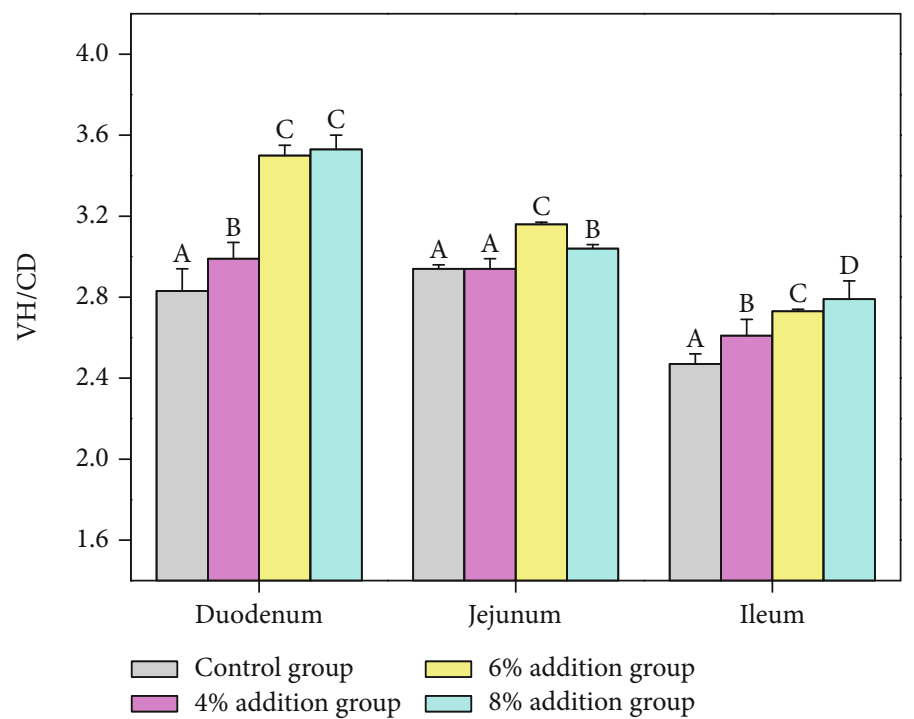

(c)

FIGURE 1: Effects of fermented maize cob feed on intestinal morphological structure of finishing pigs: (a) villus height; (b) crypt depth; (c) villus height/crypt depth. Value columns with different letters mean significant difference $(p<0.05)$, the same as below.

\section{Discussion}

Synergistic microbial fermentation techniques connect the entire process of feed fermentation, processing, and production. The combined action of microbial probiotics and enzymatic hydrolysis technology was the biggest technological breakthrough in feed fermentation and was important for the future development of biological feed [34]. The present study demonstrated that the addition of different proportions of synergistic microbial fermented maize cob feed promoted the growth, nutrient consumption, slaughter performance, and the overall intestinal health of finishing pigs. It could also replace the energy component of the basic diet part in "NRC (2012) nutrient requirements for finishing pig," and these effects were significantly enhanced as the proportion of additive increased until an equilibrium was maintained at a peak value.
The nutrient consumption rate of livestock feed was an important index to measure the digestive utilization of livestock animals and to evaluate the nutritional value of feed [35]. NSP, the principal component of plant-derived cell walls, was not easily digested or utilized by monogastric animals. In addition, water-soluble nonstarch polysaccharides (e.g., arabinoxylan and $\beta$-glucan) are highly viscous and can increase the chyme viscosity in the intestines of animals, which blocks interactions between nutrients in feed and digestive juices and affects the digestion of nutrients. The addition of NSP enzymes can eliminate or reduce the adverse effects of NSP [36-37]. NSP enzymes can degrade plant cell walls, cleave internal soluble nonstarch polysaccharides, and promote the release of nutrients bound in cell walls. Reducing the viscosity of the contents of the intestinal tract was beneficial for interactions between nutrients and enzymes and improved digestion rates [38]. On the other 


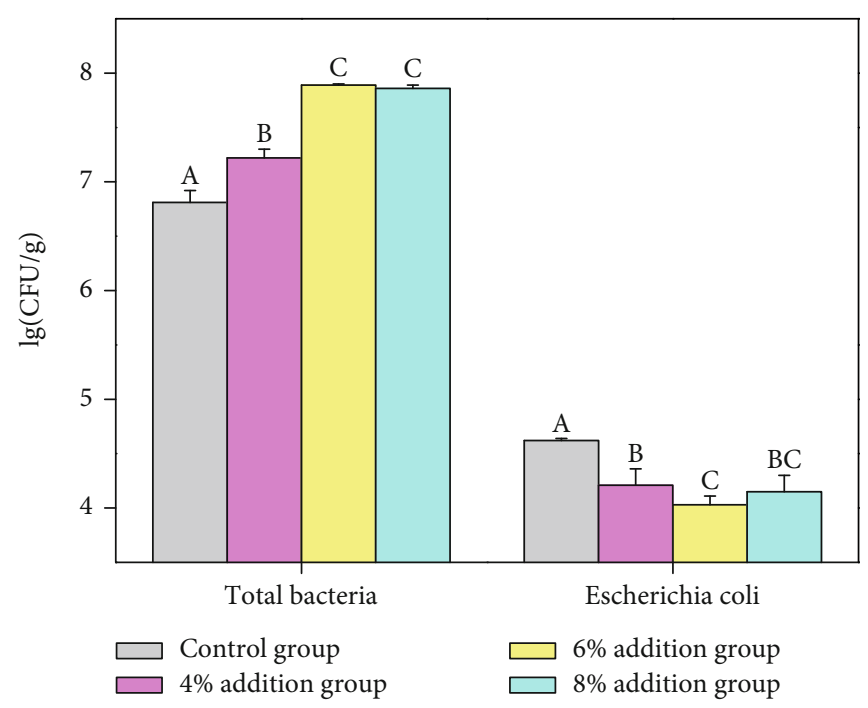

(a)

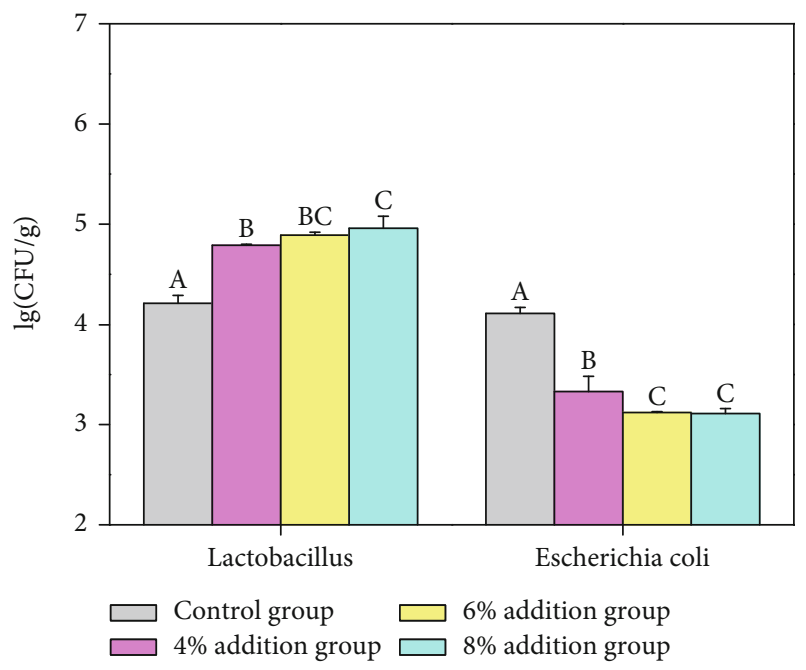

(b)

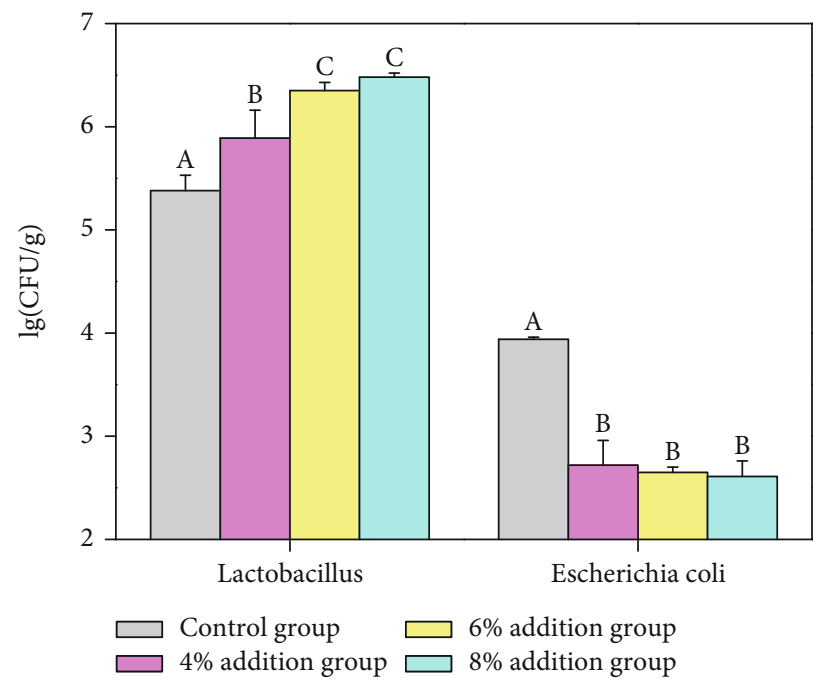

(c)

Figure 2: Effect of fermented maize cob feed on feces and intestinal microflora of finishing pigs: (a) changes in the microbial flora of feces in different test groups; (b) changes in the microbial flora of the ileum in different test groups; (c) changes in the microbial flora of the cecum in different test groups.

hand, composite probiotics in fermented feed can decompose macromolecular substances that were difficult for livestock and poultry to digest into small molecule nutrients, such as small peptides, glucose, amino acids, and vitamins, which were easily digested and absorbed by the body of the animal [39]. Additionally, lactic acid and ethanol that were secreted by probiotics during their growth also improve the palatability of feed and stimulate increased feed intake by pigs [40]. In the present study, probiotics, such as lactic acid bacteria and yeasts contained in the fermented maize cob feed, underwent synergistic fermentation with NSP enzymes. Finally, the nutrient consumption rate and nutrient digestion and absorption in the fermented maize cob feed experimental group of finishing pigs significantly increased, and the production performance of the finishing pigs (feed conversion ratio, daily weight gain) also significantly increased.
Slaughter performance and meat quality were the main indices that evaluate the performance of livestock products [41]. Adding fermented maize cob feed promotes absorption of dietary nutrients, accelerated growth rate, and increased the dressed weight and dressing percentage of finishing pigs. However, when a high proportion (8\%) of fermented maize cob feed was added, the energy intake became too high, and rapid back fat accumulation occurred, thus reducing percent lean and slaughter quality of the finishing pigs. Studies had shown that the metabolites of microorganisms can increase the cytoplasmic concentration in pork cells, increase the ability of the pork to absorb water, and reduce the drip loss of pork [42]. The present study also found that fermented maize cob feed can reduce the drip loss of pork, which may be due to enhanced enzymatic hydrolysis of nutrients in the fermented feed and increased production of metabolites from microbial growth. Moreover, the probiotics in fermented 


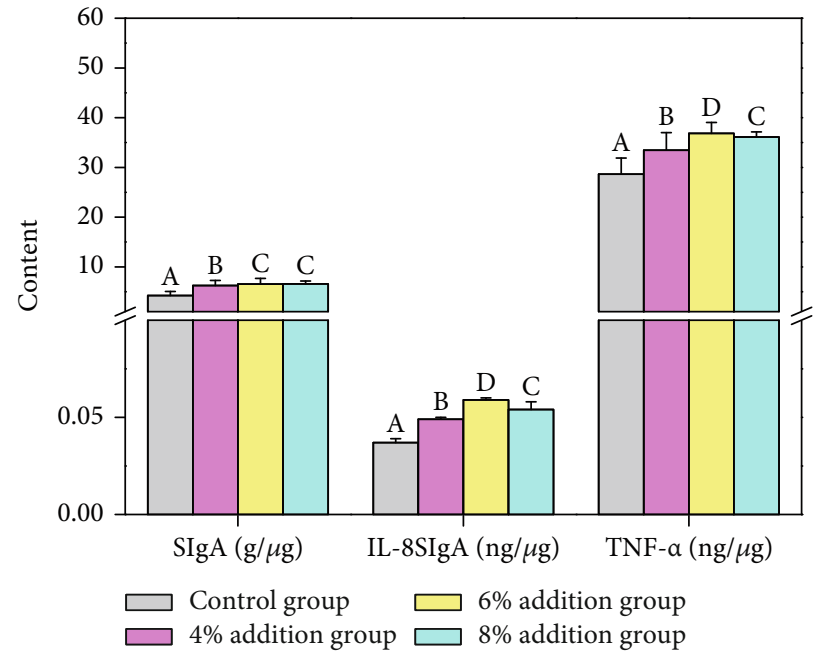

(a)

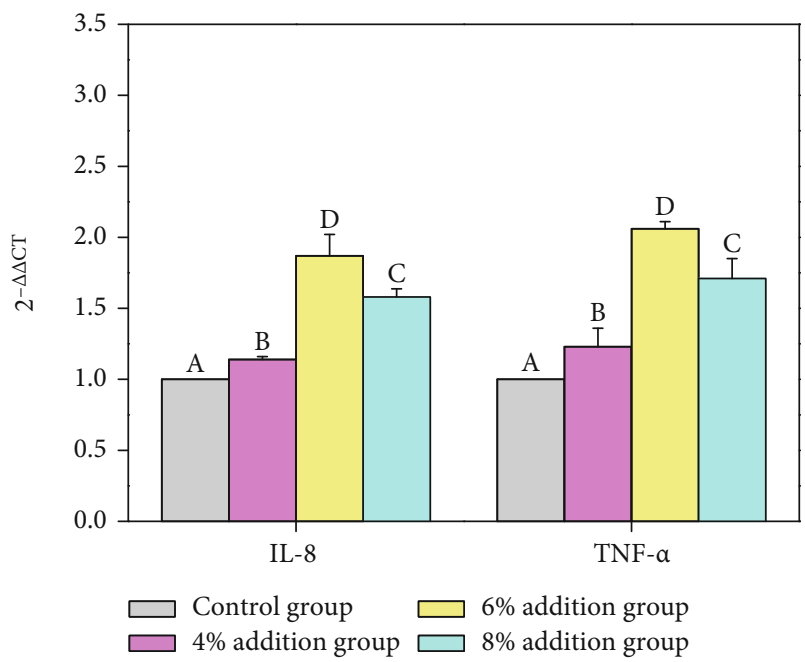

(b)

FIGURE 3: Effect of fermented maize cob feed on ileal mucosal immunity of finishing pigs: (a) changes in cytokine content in different test groups; (b) changes in gene expression of immune factors in different test groups.

maize cob feed can promote the conversion of fat into tissue by the liver and oxidative degradation, reduce fatty acid content in the liver, and simultaneously provide energy for protein synthesis, thus improving meat quality. In addition, the scent of the pork was affected by intermuscular fat and fatty acid composition. Cameron et al. and Makoto et al. found relationships between pork eating quality (tenderness, juiciness, and flavor) and muscle fatty acid composition [43-44]. In the present study, as the content of saturated fatty acids and monounsaturated fatty acids in each fermented maize cob feed experimental group increased, pork eating quality increased to some degree. Conversely, increased polyunsaturated fatty acid content led to decreased eating quality.

The balance of the microecological system in animal intestines plays an important role in improving growth rate, promoting immune system development, maintaining normal immune function, defending against pathogen invasion, and reducing disease occurrence in animals [45]. The present study found that the addition of fermented maize cob feed to the diet of finishing pigs resulted in abundant probiotics that rapidly occupied the ecological niches in the intestines of the pigs, thereby establishing growth dominance, significantly increasing the number of lactic acid bacteria in the intestines, and reducing the amount of $E$. coli in the intestines and feces. This overall improved the microecological balance in the intestines of the pig and improved physical immunity.

Morphological structural integrity, villus height, and crypt depth of the small intestines were important criteria to measure the health of the animal and its ability to digest and absorb nutrients [46]. Studies of the intestinal surface suggested that longer villi were related to the improved ability of the small intestines to absorb nutrients, shallower crypt depth related to the improved small intestinal secretion activity, and greater villus height/crypt depth ratio related to the larger intestinal lining area and higher digestive capacity [47]. In the present study, fermented maize cob feed con- tained yeast, of which its cell wall contains $\beta$-glucan and mannan, which reduce the binding of the gastrointestinal tract mucosa of pigs to antigens via the adsorption, phagocytosis, destruction, and absorption of invading bacteria. This consequently protects the gastrointestinal tract mucosa from damage, protects the morphological structural integrity of the small intestines, and promotes small intestine development and significant improvement in crypt depth and the $\mathrm{VH} / \mathrm{CD}$ ratio.

sIgA was an important effector molecule in the intestinal mucosa that can regulate intestinal microorganisms and neutralize toxins [48]. Cytokines-such as IL-8 and TNF$\alpha$-were important signaling molecules in the immune system [49]. Probiotics stimulate the expression and secretion of proinflammatory factors in the intestinal immune cells of pigs and regulate the host immune function towards a more stable state [50-51]. In the present study, fermented maize cob feed significantly increased the content of $\operatorname{sig} \mathrm{A}$ cytokines and IL- 8 and TNF- $\alpha$ immune factors in the ileum of finishing pigs, which may be due to the entry of probiotics in maize cobs into the intestines of piglets as antigens to stimulate mucosa and promote B cell proliferation and differentiation in plasma cells, which thus secretes a large amount of sIgA to improve mucosal immune function and improve disease resistance. On the other hand, the added exogenous microorganisms were recognized by the body of the animal, which stimulates the mucosa to produce a mild inflammatory response. This increased the expression of proinflammatory factors in small intestinal mucosae, which thus increased anti-inflammatory factors in the intestines, enhanced the immune function of the ileal mucosae, and improved the anti-infective capacity of the body.

However, the addition of more probiotic-fermented feed did not always lead to improvements, since an optimal dose exists $[52,53]$. The present study found that the addition of beyond $6 \%$ fermented maize cob feed slowed increases in growth performance and other growth- and production- 
related indices in finishing pigs. The basic reason behind that is that as the amount of probiotic-fermented feed increased, the stress on the intestines of the pig increased and immune factor content and expression reduced, which may eventually lead to faster fat deposition rate and lower meat quality. Given the economic benefits of overall feeding costs, the addition of $6 \%$ fermented maize cob feed was selected as an optimal dosage to feed finishing pigs.

In the present study, a combined probiotic and NSP enzyme fermentation technique was employed to prepare a fermented maize cob feed, which enhanced the degradation of maize cob composition and improved its nutritional value. The addition of $6 \%$ fermented maize cob feed to the diets of finishing pigs promoted their growth and improved their production performance, slaughter performance, and meat quality. In addition, their intestinal microecological balance was improved and their immunity was enhanced, which provides a theoretical basis and practical examples for comprehensive utilization of maize cobs and the development of microbe-fermented feed preparation techniques.

\section{Data Availability}

All data are fully available without restriction, and all relevant data are within the paper.

\section{Conflicts of Interest}

The authors declare that there is no conflict of interests regarding the publication of this paper.

\section{Acknowledgments}

This work was financially supported by the Science and Technology Planning Major Project of Fujian Province, China (no. 2020N01010238); the Qimai Technology Innovation Fund Project of Longyan Economic Development Zone (Hi-tech Zone), China (no. 2018JKQ04); the Qimai Technology Innovation Fund Project of Longyan Xinluo Zone, China (no. XLQM003); and the Open Project Programme of Key Laboratory of Fujian Universities Preventive Veterinary Medicine and Biotechnology at Longyan University, China (no. 2019KF02). The corresponding author (Xintian Zheng) hosted the Qimai Technology Innovation Fund Project of Longyan Economic Development Zone (Hi-tech Zone), China (grant number2018JKQ04) in December 2018. The project name was "Research and Application of Animal Nutrient Solution of Multifunctional Microbial Bacteria." The financial allocation is $450000 \mathrm{RMB}$, and the project is still in the study. The financially supporting body was Government of Longyan Economic Development Zone (Hi-tech Zone), China. And the Open Project Programme of Key Laboratory of Fujian Universities Preventive Veterinary Medicine and Biotechnology at Longyan University, China (grant number2019KF02) was also hosted by the corresponding author (Xintian Zheng) in Aug 2019. The project name was "Effects of Multi-Flora Compound Fermentation Preparation on Growth Performance, Nutrition Consump- tion Rate and Serum Indexes of Weaned Piglets." The financial allocation is $50000 \mathrm{RMB}$, and the project is still in the study. The financially supporting body was the Key Laboratory of Fujian Universities Preventive Veterinary Medicine and Biotechnology at Longyan University, China. The first author (Biaosheng Lin) hosted the Science and Technology Planning Project of Fujian Province, China (grant number 2020N01010238) in April, 2020. The project name was “A study on the preparation of synergistic microbial fermented maize cob feed and its feeding efficiency in finishing pigs." The financial allocation is $150000 \mathrm{RMB}$, and the project is still in the study. The financially supporting body was Fujian Science and Technology Department, China.

\section{References}

[1] D. Yin, J. Yuan, Y. Guo, and L. I. Chiba, "Effect of storage time on the characteristics of corn and efficiency of its utilization in broiler chickens," Animal Nutrition, vol. 3, no. 3, pp. 252-257, 2017.

[2] S. Zhu, Y. Guo, D. Tu et al., "Water absorption, mechanical, and crystallization properties of high-density polyethylene filled with corncob powder," BioResources, vol. 13, no. 2, pp. 3778-3792, 2018.

[3] M. Idrees, A. Adnan, and F. A. Qureshi, "Comparison of acid and alkali catalytic efficiency during enzymatic saccharification of corncob and lactic acid production," Pakistan Journal of Agricultural Sciences, vol. 51, no. 4, pp. 1049-1058, 2014.

[4] K. Jiang, H. Kuang, T. Qin et al., "Recovery of monosaccharides from dilute acid corncob hydrolysate by nanofiltration: modeling and optimization," RSC Advances, vol. 8, no. 23, pp. 12672-12683, 2018.

[5] S. R. Yang and K. L. Zhang, "Converting corncob to activated porous carbon for supercapacitor application," Nanomaterials, vol. 8, no. 8, article e181, 2018.

[6] H. Lou, X. He, C. Cai et al., "Enhancement and mechanism of a lignin amphoteric surfactant on the production of cellulosic ethanol from a high-solid corncob residue," Journal of Agricultural \& Food Chemistry, vol. 67, no. 22, pp. 6248-6256, 2019.

[7] D. Cai, Z. Dong, Y. Wang et al., "Co-generation of microbial lipid and bio-butanol from corn cob bagasse in an environmentally friendly biorefinery process," Bioresource Technology, vol. 216, no. 9, pp. 345-351, 2016.

[8] J. Aniola, J. Gawecki, J. Czarnocinska, and G. Galinski, "Corncobs as a source of dietary fiber," Polish Journal of Food and Nutrition Sciences, vol. 59, no. 3, pp. 247-249, 2009.

[9] G. Chen, C. Liu, W. Ma et al., "Co-pyrolysis of corn cob and waste cooking oil in a fixed bed," Biotransformations Production Technologies, vol. 166, no. 5, pp. 500-507, 2014.

[10] S. Zhang, H. J. Yu, and W. J. Jiang, "Seedling effects of corncob and bagasse composting substrates in cucumber," Transactions of the Chinese Society of Agricultural Engineering, vol. 31, no. 11, pp. 236-242, 2015.

[11] A. T. Kanengoni, K. Dzama, M. Chimonyo, J. Kusina, and S. M. Maswaure, "Growth performance and carcass traits of Large White, Mukota and Large White $\times$ Mukota $\mathrm{F}_{1}$ crosses given graded levels of maize cob meal," Animal Science, vol. 78, no. 1, pp. 61-66, 2004.

[12] A. T. Kanengoni, M. Chimonyo, K. H. Erlwanger, B. K. Ndimba, and K. Dzama, "Growth performance, blood metabolic responses, and carcass characteristics of grower and 
finisher South African Windsnyer-type indigenous and Large White $\times$ Landrace crossbred pigs fed diets containing ensiled corncobs," Journal of Animal Science, vol. 92, no. 12, pp. 5739-5748, 2014.

[13] A. Muktiani, E. Kusumanti, and D. W. Harjanti, "Utilization of crop corn waste as a complete feed for pregnant goats," Advanced Science Letters, vol. 23, no. 3, pp. 2624-2626, 2017.

[14] A. Ashour, M. Amer, A. Marzouk, K. Shimizu, R. Kondo, and S. el-Sharkawy, "Corncobs as a potential source of functional chemicals,” Molecules, vol. 18, no. 11, pp. 13823-13830, 2013.

[15] R. Rostika and R. Safitri, "Influence of fish feed containing corn-cob was fermented by Trichoderma sp, Aspergillus sp, Rhizopus oligosporus to the rate of growth of java barb (Puntius gonionitus)," APCBEE Procedia, vol. 2, no. 2, pp. 148-152, 2012.

[16] D. L. De Brabander, J. L. De Boever, A. M. De Smet, J. M. Vanacker, and C. V. Boucqué, "Evaluation of the physical structure of fodder beets, potatoes, pressed beet pulp, brewers grains, and corn cob silage," Journal of Dairy Science, vol. 82, no. 1, pp. 110-121, 1999.

[17] O. A. Adeyemi and F. O. Familade, "Replacement of maize by rumen filtrate fermented corn-cob in layer diets," Bioresource Technology, vol. 90, no. 2, pp. 221-224, 2003.

[18] S. Xu, J. Yang, M. Qi et al., "Impact of adding Saccharomyces cerevisiae and Lactobacillus buchneri on fermentation, aerobic stability, nutritive value, and microbial communities in corn silage," Journal of Animal Science, vol. 95, Supplement 4, pp. 135-137, 2017.

[19] C. Shi, Y. Zhang, Y. Yin et al., "Amino acid and phosphorus digestibility of fermented corn-soybean meal mixed feed with and fed to pigs," Journal of Animal Science, vol. 95, no. 9, pp. 3996-4004, 2017.

[20] C. Xu, H. Wang, and F. Yang, "Effect of an inoculant and enzymes on fermentation quality and nutritive value of erect milkvetch (Astragalus adsurgens Pall.) silages," Journal of Animal and Feed Sciences, vol. 20, no. 3, pp. 449-460, 2011.

[21] M. L. Ozduven, F. Koc, C. Polat, and L. Coskuntuna, “The effects of lactic acid bacteria and enzyme mixture inoculants on fermentation and nutrient digestibility of sunflower silage," Kafkas Universitesi Veteriner Fakultesi Dergisi, vol. 15, no. 2, pp. 195-199, 2009.

[22] G. V. Jakobsen, B. B. Jensen, K. E. Bach Knudsen, and N. Canibe, "Impact of fermentation and addition of nonstarch polysaccharide-degrading enzymes on microbial population and on digestibility of dried distillers grains with solubles in pigs," Livestock Science, vol. 178, no. 5, pp. 216-227, 2015.

[23] L. Carreón, J. M. Pinos-Rodríguez, R. Bárcena, S. S. González, and G. Mendoza, "Influence of fibrolytic enzymes on ruminal disappearance and fermentation in steers fed diets with short and long particle length of forage," Italian Journal of Animal Science, vol. 9, no. 1, pp. 83-87, 2010.

[24] P. Christensen, V. Glits $\emptyset$, D. Pettersson, and B. Wischmann, "Fibre degrading enzymes and Lactobacillus plantarum influence liquid feed characteristics and the solubility of fibre components and dry matter in vitro," Livestock Science, vol. 109, no. 1-3, pp. 100-103, 2007.

[25] R. T. Zijlstra, A. Owusu-Asiedu, and P. H. Simmins, "Future of NSP-degrading enzymes to improve nutrient utilization of coproducts and gut health in pigs," Livestock Science, vol. 134, no. 1-3, pp. 255-257, 2010.
[26] J. H. He, Feed Analysis and Detection, China Agricultural Press, Beijing China, 2nd edition, 2011.

[27] Y. Gao, G. J. Wang, H. X. Lai, and Y. X. Yang, "Probiotic fermented apple pomace affects growth performance, serum biochemical indicators and fecal microbial flora of weaned piglets," Chinese Journal of Animal Nutrition, vol. 28, no. 5, pp. 1515-1524, 2016.

[28] B. S. Lin, J. Luo, Y. M. Li, and X. Y. Yang, "Research on the effect of microbial fermentation feeds on slaughter performance and meat quality in pig with large-scale feeding," Agricultural Science \& Technology, vol. 17, no. 10, pp. 2329-2331, 2016.

[29] N. K. Morgan, D. V. Scholey, and E. J. Burton, “A comparison of two methods for determining titanium dioxide marker content in broiler digestibility studies," Animal, vol. 8, no. 4, pp. 529-533, 2014.

[30] N. Panella-Riera, M. Gispert, M. Gil et al., "Effect of feed deprivation and lairage time on carcass and meat quality traits on pigs under minimal stressful conditions," Livestock Science, vol. 146, no. 1, pp. 29-37, 2012.

[31] X. Hu, B. Lin, M. Luo, X. Zheng, and H. Zhang, "The isolation, identification, physiological property of pig-isolate Clostridium butyricum LY33 using lactic acid and its effects on intestinal function of weaned piglets," Italian Journal of Animal Science, vol. 18, no. 1, pp. 910-921, 2019.

[32] M. Collado-Romero, C. Arce, M. Ramírez-Boo, A. Carvajal, and J. J. Garrido, "Quantitative analysis of the immune response upon Salmonella typhimurium infection along the porcine intestinal gut," Veterinary Research, vol. 41, no. 2, p. 23, 2010.

[33] T. Shan, T. Wu, Y. Reng, and Y. Wang, "Breed difference and regulation of the porcine adipose triglyceride lipase and hormone sensitive lipase by TNF- $\alpha$," Animal Genetics, vol. 40, no. 6, pp. 863-870, 2009.

[34] M. Swiatkiewicz, E. Hanczakowska, and A. Olszewska, "Effect of corn distillers dried grains with solubles (DDGS) in diets with NSP-hydrolyzing enzymes on growth performance, carcass traits and meat quality of pigs / Wpływ DDGS z kukurydzy w mieszankach z udziałem enzymów hydrolizujących NSP na wyniki tuczu, cechy półtuszy oraz jakość mięsa świń,” Annals of Animal Science, vol. 13, no. 2, pp. 313-326, 2013.

[35] L. Q. Zhang, "Analysis of the factors affecting pig digestibility," China Animal Husbandry \& Veterinary Medicine, vol. 36, no. 9, pp. 174-178, 2009.

[36] K. De Keyser, L. Kuterna, S. Kaczmarek, A. Rutkowski, and E. Vanderbeke, "High dosing NSP enzymes for total protein and digestible amino acid reformulation in a wheat/corn/soybean meal diet in broilers," Journal of Applied Poultry Research, vol. 25, no. 2, pp. 239-246, 2016.

[37] L. Chen, L. X. Gao, Q. H. Huang et al., "Viscous and fermentable nonstarch polysaccharides affect intestinal nutrient and energy flow and hindgut fermentation in growing pigs1," Journal of Animal Science, vol. 95, no. 11, pp. 5054-5063, 2017.

[38] B. U. Metzler-Zebeli, S. Hooda, R. Mosenthin, M. G. Gänzle, and R. T. Zijlstra, "Fermentation affects mineral flux in the gastrointestinal tract of pigs fed diets supplemented with different viscous and fermentable non-starch polysaccharides (NSP)," Livestock Science, vol. 134, no. 1-3, pp. 82-84, 2010.

[39] Q. W. Meng, L. Yan, X. Ao et al., "Influence of probiotics in different energy and nutrient density diets on growth performance, nutrient digestibility, meat quality, and blood 
characteristics in growing finishing pigs," Journal of Animal Science, vol. 88, no. 10, pp. 3320-3326, 2010.

[40] C. Suo, Y. Yin, X. Wang et al., "Effects of Lactobacillus plantarum ZJ316 on pig growth and pork quality," BMC Veterinary Research, vol. 8, no. 1, p. 89, 2012.

[41] J. Fang, Y. Cao, M. Matsuzaki, H. Suzuki, and H. Kimura, "Effects of apple pomace-mixed silage on growth performance and meat quality in finishing pigs," Animal Science Journal, vol. 87, no. 12, pp. 1516-1521, 2016.

[42] W. K. Zhang, D. H. Yu, B. Y. Liu et al., "Effect of fermented peanut shell on production performance, carcass traits, meat quality and economic benefits of fattening pigs," China Animal Husbandry \& Veterinary Medicine, vol. 42, no. 5, pp. 1145-1151, 2015.

[43] N. D. Cameron, M. Enser, G. R. Nute et al., "Genotype with nutrition interaction on fatty acid composition of intramuscular fat and the relationship with flavour of pig meat," Meat Science, vol. 55, no. 2, pp. 187-195, 2000.

[44] K. Makoto, I. Teru, and K. Toshihiko, "Studies on relationship between sensory evaluation and chemical composit ion in various breeds of pork," Nihon Yoton Gakkaishi, vol. 38, no. 2, pp. 45-51, 2002.

[45] F. Yang, C. Hou, X. Zeng, and S. Qiao, "The use of lactic acid bacteria as a probiotic in swine diets," Pathogens, vol. 41, no. 1, pp. 34-45, 2015.

[46] T. Pauer and L. Lenhardt, "Morphological and functional differentiation of the small intestinal mucosa in pigs," Folia Veterinaria, vol. 35, no. 1-2, pp. 49-59, 1991.

[47] B. R. Dunsford, D. A. Knabe, and W. E. Haensly, "Effect of dietary soybean meal on the microscopic anatomy of the small intestine in the early-weaned pig," Journal of Animal Science, vol. 67, no. 7, pp. 1855-1863, 1989.

[48] I. Sekirov, S. L. Russell, L. C. M. Antunes, and B. B. Finlay, "Gut microbiota in health and disease," Physiological Reviews, vol. 90, no. 3, pp. 859-904, 2010.

[49] M. L. Dustin, "The immunological synapse: coordinating T cell migration and antigen recognition," Journal of Leukocyte Biology, vol. 12, no. 1, p. e59, 2001.

[50] J. S. Ko, H. R. Yang, J. Y. Chang, and J. K. Seo, "Lactobacillusplantarum inhibits epithelial barrier dysfunction and interleukin- 8 secretion induced by tumor necrosis factor- $\alpha$," World Journal of Gastroenterology, vol. 13, no. 13, pp. 19621965, 2007.

[51] H. Liu, J. Zhang, S. Zhang et al., "Oral administration ofLactobacillus fermentumI5007 favors intestinal development and alters the intestinal microbiota in formula-fed piglets," Journal of Agricultural \& Food Chemistry, vol. 62, no. 4, pp. 860-866, 2014.

[52] H. Liu, H. F. Ji, D. Y. Zhang et al., "Effects of Lactobacillus brevis preparation on growth performance, fecal microflora and serum profile in weaned pigs," Livestock Science, vol. 178, no. 6, pp. 251-254, 2015.

[53] J. Che, S. Ye, B. Liu et al., "Effects of Brevibacillus brevis FJAT1501-BPA on growth performance, faecal microflora, faecal enzyme activities and blood parameters of weaned piglets," Antonie Van Leeuwenhoek, vol. 109, no. 12, pp. 1545-1553, 2016. 